\title{
Challenges for E-Learning and Adult Students in Higher Education
}

\author{
Ana Maria R. Correia \\ Inst. Sup. Estatistica e Gestáo da Informaçáo (ISEGI), Portugal \\ Inst. Nacional de Eng., Tec. e Inovação (INETI), Portugal \\ Anabela Sarmento \\ Instituto Politécnico do Porto, Portugal
}

\section{INTRODUCTION}

The development and promotion of the strategic goal of the European Union to become a competitive and dynamic knowledge-based economy and society (Lisbon European Council, 2000) can only be achieved with the relevant technological infrastructures together with people equipped with the necessary skills and competences (European Commission, 2002). As stated in the European Council (2005, p. 7), "human capital is the most important asset for Europe." This human capital must be supported by a well-structured initial education, constantly updated by a continuous lifelong learning program, so that people can face the challenges of a series of new jobs, maybe separated by spells of shortterm contracts or even unemployment. This continuous education program should be available to all citizens, regardless of their age and social or economic status. As stated in the European Council (2006):

All citizens should develop knowledge, skills and competencies and keep them updated by education and lifelong learning. One should also take into consideration the specific needs of citizens that might be victims of social exclusion. These procedures will contribute to economic growth and will reinforce social cohesion.

In a knowledge-based society, education and training are among the highest priorities because they are central to the creation and transmission of knowledge and are a determining factor for societal innovation. It is also recognized that human resources are the main assets for every organization and country.

In this context, universities play an important role in the development of human capital as they are instrumental to enable the acquisition of such skills by all citizens, including adults. For a long time these institutions were the domain of an elite, as only the privileged ones had the opportunity to apply for a higher education course (Merrill, 2001). However, in recent years, as a consequence of changes not only in the economy but also in the labour market, leveraged by globalization, this situation has changed dramatically and now, universities have opened their doors to attract a wider range of students with a variety of backgrounds. This expansion has allowed new groups of students, traditionally excluded or under-represented in higher education, to participate (Schuetze \& Slowey, 2002); these include adult non-traditional students.

Recognising the essential role of the universities, some European policies were initiated. The Sorbonne Declaration (1998) stressed the need to create a European area of higher education as a key element to promote mobility and employability. In 1999, the Bologna Declaration recognised the need to build a European area of higher education having a system of compatibility and comparability through coordinated policies. Later, in 2005, the European Council refers to the Universities and R\&D as "the foundations of European competitiveness" (Commission, 2006, p. 2).

Although there has been an increased use of concepts, such as flexibility, choice, excellence, and personal responsibility for learning in the European political agenda, imposed on universities by governments, adult students are still expected to fit into educational institutions designed for younger ones. It creates a gap between adult students' expectations and the real situation they face when entering (or re-entering) a higher-education institution.

This article looks at the problem from the perspective of the adult learner in higher education by presenting some of the results of a project, funded by European Commission Socrates Programme, LIHE, Learning in Higher Education. It is structured as follows: first, the background of the project is described, then the experiences of the adult student, concerning their induction 
and tuition, are presented. Some future trends concerning adults in higher education and lifelong learning are outlined and conclusions drawn.

\section{BACKGROUND}

Being aware of the need to promote lifelong learning for all citizens and to encourage adults to exploit higher education so they can develop the necessary skills and competencies in order to remain competitive and contribute to the development of a knowledge-based society, the European Union launched the Grundtvig Action under the SOCRATES programme. Its aim is to promote a policy of lifelong learning at the European level as well as in each of the participating countries. The action supports all levels and sectors of adult learning, and includes learning that occurs within the formal or non-formal systems as well as on a more informal basis.

Adult students are defined in the literature as being adults over the age of 25, who left school with few or no qualifications, who have been out of the educational system for a long time, have no previous higher-education experience and come from a disadvantaged group (one or more of these conditions may apply) (Bourgeois, Duke, Guyot, \& Merrill, 1999). This definition will, therefore, include adults who are working class, women, disabled, or who belong to ethnic groups. In the last years, some projects concerning adult students and higher education have been developed. ALPINEAdults Learning and Participating in Higher Education, is one example. Its aims were to examine key issues affecting participation of adults in universities, in 20 European countries. It also explores the role of information and communication technologies in adult learning, as a means of supporting flexibility, in the learning process. The project IAML3: Introducing Appropriate Methodologies for Lifelong Learning, aims to contribute to overcoming geographic dispersal and time constraints by developing and providing online distance learning. FLEX-ALL-Flexible Learning Environment for Adult Learner aims at motivating adult learners to integrate e-learning utilities in their learning activities as one source of flexibility. Tutoring Adults Online-@duline-aims to promote the use of online learning among adult educators in lifelong learning. PILPE-Promoting ICT Learning Processes in Europe aims to identify the barriers that hinder adult learners from using ICT in their learning process, as well as identify the factors that give adult learners negative attitudes towards using ICT. WIT-Ways of Internet Teaching intends to consider the different ways and possibilities of teaching adult groups in an enlarged Europe by including the use of Internet and e-learning as a daily tool in classroom and homework. These are just a few examples of the projects being developed in Europe that see adults and their needs as a core concern (Socrates Compendium, 2002, 2006).

The LIHE project grew out of an EU Targeted Social and Economic Research project entitled University Adult Access Policies and Practices Across the European Union and their Consequences for the Participation of Non-Traditional Adults; this looked at the access of non-traditional adult students in European universities, both in terms of access to the system and their experiences while undertaking a degree program.

LIHE was a European cooperative project with seven participating institutions in different countries (Finland, Germany, Ireland, Portugal, Spain, United Kingdom, and Sweden) taking part. Its aims included:

- The promotion of lifelong learning in higher education

- $\quad$ Raising awareness, amongst practitioners and policy makers, of the learning needs of adults in higher education

- Identification of the learning experiences and needs of adult students

- $\quad$ Promotion of the lifelong learning in higher education by developing a pedagogy.

- A curriculum that will appeal to those who feel that higher education is not for them.

- Sharing good practice, promotion of the institutional change.

- Increasing of knowledge in the field

- Identification of policy recommendations for EU, at national and institutional levels

The following section examines the perspective of adult students concerning the higher education issues in Portugal, such as:

- Expectations regarding highereducation, learning, and teaching approaches

- Difficulties regarding their participation in a higher-education program 
- The adult types of students, taking into consideration the types already identified by Alheit and Merrill (Merrill, 2003)

The authors are convinced that those implementing the use of ICT and Internet solutions, to deliver programmes for adult learners, need to know in advance the typology of adult students concerned.

\section{MAIN FOCUS: RESULTS FROM THE PORTUGUESE CASE STUDY}

Some idea of adult learning experiences and needs was obtained through in-depth biographical interviews of mature students. Twelve students from one University ( 8 men and 4 women) and 8 students from one Polytechnic School ( 2 men and 6 women) were interviewed. There were 5 men and 1 woman below 30 -years old, 5 men and 3 women between 30 and 40, and 6 women above 40 . They were invited to give an account of their working lives, family situation, and initial schooling. In short, we asked them to tell the story of their lives (Polkinghorne, 1995), as one way to understand adult learners' past experiences and their ambitions for the future. The student was asked to tell his/her story concerning school courses and the interviewer just intervened to direct the interviewee towards one topic or another (e.g., asking him/her about pedagogical approaches or assessment methods). Interviews were carried out between July and September 2003. This methodological approach enabled us to obtain data that informs the type of learning and teaching methodologies and institutional strategies that are needed to accommodate such students. The topics and questions aimed at eliciting data about the reasons why they decided to return to their studies, at a certain moment in their lives, as well as their teaching and learning experiences, preferences, and difficulties. A summary of the interview results, addressing:

- "Expectations regarding attendance in higher education"

- "Learning and teaching approaches"

- "Difficulties felt during attendance of higher education classes"

are all presented in the following sections. For further details concerning these issues, see Correia, Merrill, and Sarmento (2003).

\section{Expectations Regarding Attendance in Higher Education}

Adult students return to higher education because they wish to achieve a dream they always had or because they want to change something in their lives (profession or career). This desire for change might have been triggered by an increase in competition in the marketplace, or a recognition of the need to finish secondary-level education prior to seeking a higher-education course of studies, as insurance against unemployment. Such a decision might also be triggered by some disappointment that the student is feeling in his/her present job, the lack of recognition of his value as an unqualified employee or due to some pressure in the organization to obtain a higher-education degree.

The interruption of studies can happen because the course initially attended was not what they expected or wanted. Generally, the choice of that first course of study was not made by them but usually by their parents. The interruption can also be caused by the student being unable to secure a place in the course of choice and obliged to enrol in another one that was abandoned some years later. Sometimes the desired course would not exist in the town where the student lived, forcing him/her to enrol in another one. Lack of information at the critical time of choosing, family difficulties or problems keeping up attendance are all other reasons for interruption.

\section{Learning and Teaching Approaches}

The learning and teaching approaches usually used in classes are lectures and project work, which they prefer, even though recognising that it takes up a lot of time (which they do not have). They say that they learn better and in more depth with this methodology because it makes them study continuously (instead of studying only for examinations), and obliges them to do research and fully understand a subject.

As far as the lectures are concerned, the interest in a discipline depends greatly on the lecturer and on his/ her capability to motivate the student. Learners prefer lecturers who know how to teach, how to present the subject, how to involve the student in the subject, and being available to clarify any doubts that may arise.

However, some problems were also reported. For instance, not all the lecturers seem to have a sympathetic pedagogical attitude; they see mature students as if they 
were traditional young ones, fresh from school, and seem to forget that adults have other responsibilities and make a significant sacrifice to attend classes every day. Sometimes, lecturers also choose to ignore prior knowledge or experience of the adult student.

The students interviewed suggested that classes should be more practical and participative, and that the relationship between the subject and the real world should be better established. They also suggest that the subject should be summarized in one or two overhead slides and that classes should be broken into small groups; they could then be asked to solve real cases. In this way, the students felt that they would become more involved with the subject and learn more effectively.

Students prefer being assessed by their project work rather than the examination as, in the latter, something might go wrong and the effort of a semester would be lost. Almost all the interviewees prefer to have continuous assessment. Some students also feel that their presence in classes and their participation should also be taken into consideration for assessment purposes; this opinion is not shared by every student, as some say that they already know what is being taught or that they are too shy to participate.

\section{Difficulties Regarding Their Participation in Higher Education Programme}

The majority of the students work and study at the same time and so, they say that they do not have time to spare. They arrive late at home in the evening and on the following day everything starts again. They do not have time to study (they study late in the evening or at the weekends, "stealing" time from their families) and have few opportunities to work in groups with their colleagues. Some adult students reported that they were initially afraid of feeling like an outsider and not being accepted, because of their age. However, they soon realised that their younger colleagues welcomed them and this problem soon disappeared. Sometimes, students also have problems understanding a particular subject, because they cannot see the way that it integrates with others. They need to see the "the whole picture."

Administrative services also cause some problems. Very often students have to miss classes in order to attend to administrative matters (for example, academic services do not open in the evening or if they do, it is only for a very short period, not long enough to meet the requirements of every adult student).
Finally, it is has been said that some lecturers are not sensitive to students' problems (e.g., time to do homework, to finish projects, and be more flexible with deadlines). Lecturers should also take into consideration the student's prior knowledge and experience; it can be very boring to hear a lecturer presenting the basics when some students already know more at an advanced level. However, knowing "how to do" must always be complemented by an understanding of the basic theories and the logic. Perhaps the solution is to find a balance between what the student knows and ensuring that the first principles are understood and applied.

\section{Types of Students}

In this section, the types of Portuguese adult students are presented. Analysis took into consideration the student types previously identified-patchworker, educational climber, integrator, emancipator, careerist, hesitator, postponer and formalizer-by other partners in the project (Merrill, 2003). The Portuguese dominant types are as follows: the careerist, the thirsty for knowledge/self developer and the formalizer. Some of the students fit under more than one type.

\section{Careerist}

This person usually goes to university for prestige and financial reasons. They are extrinsically motivated by economic factors; they see academic studies as providing a way to reach a goal, such as a better job. They are ambitious people. S/he usually intends to take more courses after the completion of the current one. S/he might already have attended other higher-education courses (for instance, a Bacharelato in a Polytechnic), but as it was not what s/he wanted (for instance, the course might have been chosen by others, usually parents), s/he decided to start again. This person might be also intrinsically motivated and wanting to be part of the academic world.

\section{Formalizers}

These students return to higher-education institutions because they feel that they are not fully appreciated where they work, they feel marginalized or even outsiders. They can be experts in some areas, but this knowledge is not recognized or given value at work because it does not constitute a formal qualification. 
Some of these students might already have attended, totally or partially, a course in a higher-education institution. However, the choice of that course might not have been made by the student but by someone else. This person might also have attended other courses (professional ones) in which they have acquired the minimum knowledgeto perform the job adequately. This knowledge might also have been acquired informally. In the enterprise where they work, this knowledge is not recognized formally preventing this person from applying for a higher post or having a successful career (they do not have the minimum formal qualifications). They then return to higher-education institutions to get the degree required, and to formalize their knowledge so they can be appreciated at work. Eventually, there might be students that were disappointed with the courses they were attending, or with the institutions where they were studying, and so they left. Furthermore, it is possible to identify a Portuguese cultural bias among these students; usually Portuguese management gives more value to the degree than to the knowledge and capability of the individual.

\section{Thirsty (for Knowledge)/Self Developers}

For these students, the purpose of the degree is to satisfy their desire to have more knowledge about a particular subject. It is not related to a career or to fulfil the dreams of someone else. Some students refer to their passion for books. The reason that these students return to higher education is the desire to learn, which in some cases, has its origin in the student or was triggered by others. Sometimes, the return is influenced by the fact that the student has more free time that can be dedicated to study (for instance, children are already at school or at university).

\section{FUTURE TRENDS}

The adult learner is often assumed to be an autonomous learner, which might not be the case (and usually is not). So, research is needed to determine the best way to help the student become a self-directed learner (Brookfield, 1998) or an independent learner. Furthermore, the process of how the student develops his/her knowledge is little understood and researched, but it is widely recognised that the adult student brings to education a wealth of experience, learnt informally in daily situations.

With a policy of encouraging people to return to school, more and more adults enter higher education. However, higher-education institutions remain much the same as they were at the beginning of the $20^{\text {th }}$ century. A great deal is still to be done if we are to understand the learning characteristics of adults, so that they can be fully integrated in the education system.

Moreover, with the rapid change characteristic of a knowledge-based society, the need to continuously learn is obvious. All citizens, regardless of their situation or age, should return to school for retraining, whenever they see their skills and experience being devalued and overtaken by technological advance. How can those citizens be encouraged to do so? What changes should the university make in order to accommodate them? What skills and knowledge should they acquire to meet the challenge? These are some questions that deserve to be answered by future research.

\section{CONCLUSION}

The results of this project show that, if higher-education institutions want to attract new audiences and present themselves as the basis upon which to build a knowledge-based society, offering an education based on quality and excellence, they must take into consideration the needs and expectations of their adult students. Information and communication technologies must be exploited to improve the following conditions for adult students in higher education:

- Meet expectations

- Improve learning and teaching methodologies

- Understand and overcome difficulties faced by adults in higher education programmes

\section{REFERENCES}

Bourgeois, E., Duke, C., Guyot, J. L., \& Merrill, B. (1999). The adult university. Buckingham, UK: Society for Research into Higher Education \& Open University Press. 
Brookfield, S. (1998). Critically reflective practice. Journal of Continuing Education in the Health Professions, $18(4$ - Fall), 162-184.

Commission of the European Communities. (2000). Memorandum on lifelong learning. Luxembourg: Office for Official Publications.

Commission of the European Communities. (2001). Making a European area of lifelong learning a reality. Luxembourg: Office for Official Publications.

Commission of the European Communities. (2006). Delivering on the modernisation agenda for universities: Education, research and innovation. COM (2006) 208 final, $10^{\text {th }}$ May 2006. Retrieved April 10, 2007, from http://ec.europa.eu/eracareers/pdf/COM(2006)_208. pdf

Correia, A. M. R., Merrill, B., \& Sarmento A. (2003). Improving the learning experience and learning environment of adults in higher education - Project LIHE: the Portuguese. In Proceedings of the ESREA Fourth Access Network Conference, Equity, Access and Participation: Research, Policy and Practice, 11 - 13 December 2003. Edinburgh, Scotland.

European Commission. (2002). Innovation tomorrow - innovation policy and the regulatory framework: making innovation an integral part of the broader structural agenda, Luxemburg: Office for Official Publication.

European Council. (2005). Council conclusions of 24th May 2005 on new indicators in education and training. OJEU 2005/C 141/04 of 10.6.2005, pp. 7-8. Retrieved April 10, 2007, from http://eur-lex. europa.eu/LexUriServ/site/en/oj/2005/c_141/c_ 14120050610en00070008.pdf

European Council.(2006). Modernising education and training: A vital contribution to prosperity and social cohesion in Europe 2006 joint interim report of the council and of the commission on progress under The 'education \& training 2010'work programme (2006/C 79/01). OJEU C 79 of 01.04.2006]. Retrieved April 10, 2007, from http://eur-lex.europa.eu/LexUriServ/site/ en/oj/2006/c_079/c_07920060401en00010019.pdf

Knowles, M. (1980). The modern practice of adult education. From pedagogy to andragogy (2nd ed.). Englewood Cliffs, NJ: Prentice Hall.
Kolb, D. A. (1984). Experiential learning: Experience as the source oflearning and development. Englewood Cliffs, NJ: Prentice-Hall.

Lisbon European Council. (2000). Presidency conclusions - 23-24 March 2000. Retrieved May 15, 2007, from http://ue.eu.int/Newsroom/LoadDoc.asp?BID=7 $6 \& \mathrm{DID}=60917 \& \mathrm{LANG}=1$

Merrill, B. (2001). Learning and teaching in universities: Perspectives from adult learners and lecturers. Teaching in Higher Education, 6(1), 5-17.

Merrill, B. (2003). Learning in universities: Identifying biographies of adult students. In Proceedings of the ESREA Fourth Access Network Conference Equity, Access and Participation: Research, Policy and Practice, 11 - 13 December 2003. Edinburgh, Scotland.

Polkinghorne, D. (1995). Narrative configuration in qualitative analysis. In Hatch \& Wisniewski (Eds.), Life history and narrative. London: The Falmer Press.

Schuetz, H., \& Slowey, M. (2002). Participation and exclusion: A comparative analysis of non-traditional students and lifelong learners in higher education. International Journal of Higher Education and Educational Planning, 44.

Socrates Compendium. (2002). Grundtvig - European Cooperation Projects and Networks In Adult Education. Retrieved May 15, 2007, from http://europa. eu.int/comm/education/programmes/socrates/grundtvig/compendium2002.pdf

Socrates Compendium. (2006). COMPENDIUM 2006 - GRUNDTVIG 2 - LEARNING PARTNERSHIPS. Retrieved May 15, 2007, from http://ec.europa.eu/education/programmes/1lp/grundtvig/doc/comp2_06.pdf

\section{KEY TERMS}

Andragogy: This concept was first developed by Knowles in the late 1960s as a science of teaching adults; its key assumptions, based on the characteristics of adult learners, are:

1. Self-directedness and independence increases as a person matures.

2. Adult experience constitutes a resource for learning. 
3. Readiness to learn is related to "needs," which in turn are related to the different developmental tasks, phases and roles of adult life.

4. As a person matures, his/her orientation to learn is more directed towards the immediacy of application and to one of problem centeredness.

5. In the adult, learning motivation is intrinsic.

Biographical Analysis: Is an interpretive research approach to understand how individuals take part in social contexts and make sense of them. The analysis of the interviews helps to reveal the structures of personal and social processes of action. Usually, at the beginning of the interview, there is nothing that would be recognised as "relevant categories"; these should emerge from the analysis of data.

Experience-Based Learning (or experiential learning): This learning model, first developed by David Kolb, positions the learner and his experience in the centre of all activities. This experience comprises all kind of events in the life of the learner, including those that happened earlier, the current events, or those arising from the learner's participation in activities implemented by teachers and facilitators. The experience analysis, by reflecting, evaluating, and reconstructing, is a key element. It encompasses formal, informal and non-formal learning, lifelong learning, incidental learning, and workplace learning.

Learning Contracts: Are agreements negotiated between a learner and a teacher stating that certain activities will be undertaken to achieve particular learning goals and that specific evidence will be produced to demonstrate that the goals have been reached. This agreement is a mechanism for reassuring both parties involved about whether a piece of work will meet the requirements of a certain course or module. It is based on the idea that learners are active partners in all the learning and teaching process.

Lifelong Learning: All learning activity undertaken throughout life, with the aim of improving knowledge, skills, and competences within a personal, civic, social, and/or employment-related perspective. Lifelong learning is about the acquisition and update of all kind of abilities, interests, knowledge, and qualifications from the preschool years to post retirement. It also values all forms of learning, including formal learning, nonformal learning, and informal learning.

Reflexive Learner: This type of learner is someone who explores their experiences of learning to better understand how they learn and improve their learning and thus, becoming a lifelong learner. This kind of student is more self-aware and self-critical, honest about themselves and open to criticism and feedback, curious and prepared to try different approaches, motivated to improve and more able to carry through independent learning. Strategies that may help to improve and encourage reflection include self- and peer assessment, learning logs, critical incident and fieldwork diaries, reflective commentaries, and action research.

Social Learning Theory: Can be defined as the combination of learning and problem solving activities that take place within participatory systems such as groups, social networks, movements and collectives, operating within real-life contexts and thereby raising issues of social responsibility. It combines learning, problem solving, sociability, and responsibility. 